Jurnal Akuntansi dan Keuangan (JAK)

P- ISSN: 2301-4717 E-ISSN: 2716-022X

Homepage: https://ojs.unimal.ac.id/index.php/jak/index

\title{
Pengaruh Beban Pajak Tangguhan, Profitabilitas, dan Leverage Terhadap Manajemen Laba
}

\author{
Muhamad Satrio Wibisono ${ }^{1 *}$, Nuramalia Hasanah ${ }^{2}$, Hafifah Nasution ${ }^{3}$, I Gusti Ketut Agung Ulupui ${ }^{4}$, Indah \\ Muliasari ${ }^{5}$ \\ Universitas Negeri Jakarta \\ *Coresponding author: mswibisono1103@yahoo.com | Phone Number: 08558409597 \\ DOI: https://doi.org/10.29103/jak.v10i1.6362
}

\section{ARTICLE INFO}

Received: 20-01-2022

Received in revised: 14-02-2022

Accepted: 15-02-2022

Available online: 01-03-2022

\section{KEYWORDS}

Defered Tax Expense;

Profitability;

Leverage;

Earnings Management;
A B S T R A C T

This study aims to determine the effect of deferred tax expense, profitability, and leverage. The independent variables used in this study are deferred tax expense, profitability and leverage. The dependent variable used in this study is earnings management. This study uses secondary data, namely financial statements and annual reports of companies listed on the Indonesia Stock Exchange (IDX) for the 2018-2020 period with a total of 84 observations. The sampling method used in this study is the purposive sampling method. This study uses multiple linear regression analysis which is processed using the SPSS 26 application. The results show that deferred tax expense has no effect on earnings management. Profitability has a positive effect on earnings management. Leverage has a negative effect on earnings management.

\section{PENDAHULUAN}

Dalam dunia usaha laporan keuangan merupakan media komunikasi dimana laporan keuangan bisa menghubungkan pihak-pihak yang berkepentingan terhadap perusahaan dengan menyajikan laporan keuangan seadanya. Pihak-pihak yang berkepentingan seperti investor, kreditor dan pemilik perusahaan dapat mengestimasi keandalan laporan keuangan terutama laba untuk mengukur risiko dalam investasi dan kredit, karena laba perusahaan masih sangat diperhitungkan sebagai informasi yang penting bagi investor, kreditur serta pemilik perusahaan. Laba perusahaan menjadi target rekayasa bagi pihak manajemen agar dapat menarik kinerja yang lebih baik sehingga mendapatkan benefit atau meningkatkan income. Dengan memilih kebijakan akuntansi tertentu, pihak manajemen sebagai pelaksana serta penanggung jawab operasional perusahaan dapat mengkontrol laba perusahaan sesuai dengan keingininan. Kualitas laba suatu perusahaan sangat di perhatikan oleh pihak manajemen namun, penyusunan laporan keuangan berbasis akrual, sebagaimana yang diatur dalam PSAK 1 (IAI, 2013), sehingga memungkinkan manajemen bertindak sesuai dengan kepentingan atau biasa di kenal dengan istilah manajemen laba.

Manajemen laba merupakan salah satu upaya dari pihak manajer dalam mengelola dan mengatur laba sebuah perusahaan untuk memeroleh keuntungan bagi pihak perusahaan maupun pihak lain demi kesejahteraan bersama (Maslihah, 2019). Pentingnya informasi mengenai laba atau keuntungan pada perusahaan dapat memungkinkan manajemen perusahaan melakukan tindakan oportunis yang merugikan dan merekayasa laporan laba perusahaan agar terlihat baik.

Menurut (Yogi \& Damayanthi, 2016) Manajemen laba adalah upaya untuk mengubah, menyembunyikan, dan merekayasa angka-angka dalam laporan keuangan dan mempermainkan metode dan prosedur akuntansi yang digunakan perusahaan. Upaya perusahaan untuk merekayasa informasi melalui praktik manajemen laba telah menjadi faktor utama yang membuat laporan keuangan tidak lagi mencerminkan nilai fundamental suatu perusahaan. Oleh karena itu, perekayasaan laporan keuangan telah menjadi isu sentral sebagai sumber penyalahgunaan informasi yang dapat merugikan pihak-pihak yang berkepentingan, hal tersebut menyebabkan informasi yang diterima tidak sesuai dengan keadaan yang sebenarnya.

Fenomena praktik manajemen laba kerap terjadi, baik di dalam negeri maupun luar negeri. Adanya beberapa kasus mengenai praktik manajemen laba yang terjadi perusahaan-perusahaan besar baik di level lokal maupun internasional. Seperti contohnya kasus PT Tiga Pilar Sejahtera Food Tbk (AISA) pada tahun 2019 yang dimuat cnbcnindonesia.com oleh Irvan Arviano Arief. Dalam kasus ini, PT Tiga Pilar Sejahtera Food Tbk (AISA) dipanggil oleh pihak Bursa Efek Indonesia (BEI) untuk dimintai keterangan terkain hasil investigasi laporan keuangan tahun 2017 oleh Ernst \& Young Indonesia (EY). Hasil investigasi menyatakan terdapat temuan terhadap mengelembungnya pos akuntansi sebesar Rp4 triliun, diantaranya 
Rp662 miliyar pembengkankan pendapatan, Rp329 miliyar pada pos EBITDA (laba sebelum bunga, pajak, depresiasi, dan amortisasi) dan adanya aliran dana Rp1,78 triliun kepada pihak-pihak yang diduga terafiliasi dengan manajemen laba.

Terdapat beberapa faktor yang bisa mempengaruhi manajemen laba, tetapi peneliti menggunakan varibel beban pajak tangguhan, profitabilitas, dan leverage. Faktor pertama yang dapat memengaruhi perusahaan melakukan tindakan praktik manajemen laba adalah untuk meminimalisir pajak perusahaan atau untuk menarik investor agar tertarik untuk investasi. Menurut Hidayati dan Zulaikha (2003) dalam Rahmanto (2017), sejumlah pajak wajib dibayar oleh perusahaan dengan menggunakan laba sebagai dasar perhitungan. Semakin besar laba yang diperoleh, maka akan semakin besar pajak yang harus dibayarkan kepada pemerintah. Sebaliknya, semakin kecil laba perusahaan, maka akan semakin kecil pajak yang harus ditanggung oleh perusahaan. Oleh karena itu rekayasa laba dilakukan oleh manajer untuk memengaruhi hasil akhir laporan keuangan dan meminimalisir pajak yang harus dibayar oleh perusahaan. Kecenderungan perusahaan untuk mengurangi laba yang dilaporkan berhubungan dengan teori akuntansi positif, sehingga beban pajak tangguhan dapat memengaruhi manajemen laba sebagai motivasi penghematan pajak. Suandy (2003) dalam (Suputra, 2017) menyatakan bahwa dengan adanya keinginan pihak manajemen untuk menekan dan membuat beban pajak sekecil mungkin, maka pihak manajemen cenderung untuk meminimalkan pembayaran pajak sebagai upaya untuk meminimalkan beban pajak.

Faktor kedua yang menjadi alasan perusahaan melakukan manajeman laba adalah profitabilitas karna pihak investor akan melihat dari sisi profitabilitas perusahaan maka dari itu profitabilitas menjadi alasan sebagai tindak melakukan manajemen laba. Tala dan Karamoy (2017) dalam (Fandriani, 2019) menyatakan bahwa profitabilitas merupakan kemampuan perusahaan dalam memperoleh laba bersih sehubungan dengan penjualan, total aset, maupun modal sendiri. Menurut (B.Setyawan \& Harnovinsah, 2014) apabila profitabilitas yang dihasilkan perusahan terlalu tinggi berarti perusahaan berhasil memperoleh laba yang baik. Laba yang baik cenderung mengurangi motivasi manajemen dalam melakukan manajemen laba karna jika labaa yang dihasilkan sudah cukup baik pihak. Namun sebaliknya, bila laba perusahaan kurang baik maka perusahaan akan cenderung melakukan manajemen laba.

Faktor ketiga yang dapat memengaruhi manajemen laba adalah besarnya leverage yang dimiliki perusahaan. Menurut (Anak Agung Mas Rattih Astari, 2017) leverage menjadi salah satu alternatif sumber dana perusahaan selain menjual saham di pasar modal. Leverage mampu mengukur seberapa besar aset perusahaan yang dapat dibiayai oleh utang. Menurut Agustina (2013) dalam (Fandriani, 2019) leverage dapat berpengaruh terhadap manajemen laba. Hal ini yang disebabkan manajer berusaha menghindari kegagalan pada perjanjian utang dan tingkat leverage yang tinggi memotivasi untuk menghasilkan laba yang baik. Penelitian yang dilakukan oleh (Maslihah, 2019) menyatakan bahwa leverage berpengaruh positif terhadap manajemen laba. Artinya, leverage memiliki peran penting untuk mendorong manajamen melakukan pengelolaan laba untuk menghindari terjadinya pelanggaran perjanjian utang.

\section{TINJAUAN TEORI}

\section{Teori Akuntansi Positif}

(Suputra, 2017) Teori akuntansi positif pertama kali dikemukakan oleh William H. Beaver (1968) dengan terbitnya artikel yang berjudul "The Information Content Of Annual Earnings Annoncement". Selanjutnya teori akuntansi positif diakui kemunculannya pada saat Watts dan Zimmerman mempublikasikan artikelnya yang berjudul "Towards a Positive Theory of Accounting Standard" pada tahun 1978. Artikel tersebut telah menjadikan teori akuntansi positif sebagai paradigma riset akuntansi yang dominan yang berbasis empiris kualitatif dan dapat digunakan untuk menjustifikasi berbagai teknik atau metode akuntansi yang sekarang digunakan atau mencari model terbaru untuk pengembangan teori akuntansi dikemudian hari.

Kehadiran teori positif telah memberikan kontribusi yang berarti bagi pengembangan akuntansi. Adapun kontribusi teori akuntansi positif terhadap pengembangan akuntansi adalah menghasilkan pola sistematik dalam pilihan akuntansi dan memberikan penjelasan spesifik terhadap pola tersebut, memberikan kerangka yan dimana dalam memhami akuntansi, menunjukan peran utama contracting cost dalam teori akuntansi, menjelaskan mengapa akuntansi digunakan dan memberikan kerangka dalam memprediksi pilihan-pilihan akuntansi, mendorong riset yang relevan dimana akuntansi menekankan pada prediksi dan penjelasan terhadap fenomena akuntansi.

\section{Manajemen Laba}

Menurut Sulistyanto (2008) dalam (Fitriya et al., 2020) menyatakan bahwa manajemen laba ialah cara manajer perusahaan untuk menjelaskan atau memengaruhi informasi pada laporan keuangan dengan tujuan untuk memengaruhi kinerja dan kondisi perusahaan. Menurut Scott (2003) dalam Endriati (2016) mendefinisikana manajemen laba sebagai tindakan yang dilakukan melalui pilihan kebijakan akuntansi untuk memperoleh tujuan tertentu, misalnya untuk memenuhi kepentingan sendiri atau meningkatkan nilai pasar perusahaan mereka.

Berdasarkan dua definisi ini dapat disimpulkan bahwa manajemen laba merupakan suatu tindakan yang disadari oleh pihak manajer untuk kepentingan tertentu. Model-model pengukuran discretionary accruals untuk mengasumsikan bahwa adanya komponen non-discretionary accruals berasal dari total accruals. Beberapa bukti empiris menunjukan bahwa perusahaan secara aktif mempraktikkan manajemen laba apabila memanipulasi laporan keuangan maka disumpulkan earnings quality bersifat positif.

$$
\begin{gathered}
\text { NDAit }=\beta 0(1 / \text { At }-1)+\beta 2(\Delta \text { SALESit }-\Delta \text { TRit } / \text { TAit }-1)+\beta 3(\text { PPEit } / \text { TAit }-1) \\
D A_{i t}=\frac{T A_{i t}}{A_{i t-1}}-N D A C_{i t-1}
\end{gathered}
$$




\section{Beban Pajak Tangguhan}

Beban pajak tanguhan adalah salah satu pendekatan yang dapat digunakan untuk mendeteksi adanya praktik manajemen laba yang dilakukan oleh manajemen perusahaan. Beban Pajak Tangguhan terjadi karena perbedaan yang timbul antara akuntansi pajak (laba fiskal) dan komersial dapat menyediakan informasi tambahan bagi pengguna laporan keuangan untuk menilai kualitas current earnings (Philips, 2003). Alasannya karena peraturan perpajakan lebih membatasi keleluasaan penggunaan diskresi dalam menghitung penghasilan kena pajak, itulah sebabnya selisih laba komersial dan laba fiskal (book-tax gap) dapat menginformasikan tentang diskresi manajemen dalam proses akrual (Halim, 2005) dalam (Suputra, 2017).

Pada dasarnya, beban pajak tangguhan yang disajikan dalam laporan komersial laba rugi perusahaan dapat memengaruhi jumlah nominal laba bersih setelah pajak. Hal ini dijelaskan oleh Muljono (2006) yang mengungkapkan bahwa apabila perushaaan secara komersial menghitung PPh yang terutang belum memperhitungkan koreksi fiskal maka akan menyebabkan perbedaan dengan perhitungan PPh terutang menurut fiskus, sehingga besarnya PPh terutang akan memengaruhi posisi neraca secara laporan komersial. Perbedaan besarnya pajak terutang tersebut harus dilakukan dengan membuat jurnal penyusuain yang akan berpengaruh pada besarnya rekening utang pajak dan juga memengaruhi besarnya laba setelah pajak yang diakui oleh perusahaan dalam laporan laba rugi. Atas perubahan tersebut, perusahaan harus melakulan revisi pada posisi neracanya.

$$
\mathrm{BPT}=\frac{\text { Pajak } \text { Tangguhan }}{\text { Total Aset }-1}
$$

\section{Profitabilitas}

Menurut (Budi Setyawan, 2014), profitabilitas atau kemapuan memperoleh laba adalah suatu ukuran dalam presentase yang digunakan untuk menilai sejauh mana perusahaan mampu menghasilkan laba pada tingkat yang dapat diterima. Angka profitabilitas dinyatakan antara lain dalam angka laba sebelum atau sesudah pajak, laba investasi, pendapatan per saham, dan laba penjualan.

Profitabilitas perusahaan adalah salah satu dasar penilaian kondisi suatu persuhaan, untuk itu dibutuhkan suatu alat analisis untuk bisa menilainya. Perusahaan, untuk itu dibutuhkan suatu alat analisi untuk bisa menilainya. Dengan demikian setiap perusahaan akan meningkatkan profitabilitasnya, karena semakin tinggi tingkat profitabilitas suatu badan usaha maka kelangsungan hidup badan usaha tersebut akan lebih terjamin.

Profitabilitas merupakan salah satu indikator penting yang dapat digunakan untuk menilai suatu perusahaan. Selain untuk mengukur kemampuan suatu perusahaan dalam menghasilkan laba, profitabilitas adalah hasil bersih dari berbagai kebijaksanaan dan berbagai macam keputusan. Return on assets (ROA) diukur dengan membagi laba bersih dengan total assets perusahaan. Menurut Sudarmadji dalam (Muhammad Ardiansyah et al., 2013) profitabilitas merupakan indicator kinerja manajemen dalam mengelola kekayaan perusahaan yang ditunjukkan oleh laba yang dihasilkan suatu perusahaan. Ratio profitabilitas yaitu merupakan rasio yang menggambarkan kemampuan perusahaan dalam menghasilkan laba melalui semua kemampuan dan sumber daya yang dimilikinya, yaitu yang berasal dari kegiatan operasional penjualan, penggunaan aset, maupun pengunaan modal.

$$
\text { Return On Assets }=\frac{\text { Laba bersih }}{\text { Total Aset }}
$$

\section{Leverage}

Menurut Riyanto (2016) dalam Fandriani, (2019), leverage adalah rasio yang mengukur sejauh mana pengunaan utang yang digunakan oleh perusahaan yang digambarkan melalui hubungan antara utang perusahaan terhadap modal atau aset. Biasanya perusahaan akan memanipulasi leverage karana jika tingkat leverage rendah pihak kreditor akan lebih mudah memberikan pinjaman.

Pengertian lain dari leverage menurut Syamsuddin (2011) dalam Saputra (2018) adalah kemampuan perusahaan untuk mengunakan aset atau dana yang mempunyai biaya tetap (fixed cost asets or funds) untuk memperbesar tingkat penghasilan (return) bagi pemilik perusahaan.

Kebijakan leverage timbul jika perusahaan dalam membiayai kegiatan operasionalnya menggunakan dana pinjaman atau dana yang mempunyai beban tetap seperti beban bunga. Tujuan perusahaan mengambil kebijakan leverage yaitu dalam rangka meningkatkan dan memaksimalkan kekayaan dari pemilik perusahaan itu sendiri. Leverage selalu berurusan dengan biaya tetap operasi maupun biaya finansial. Biaya tetap operasi adalah biaya yang harus dikeluarkan oleh perusahaan karena mengadakan kegiatan investasi, baik itu investasi perlengkapan, peralatan ataupun juga investasi jangka panjang.

$$
\text { Debt to Asset Ratio }=\frac{\text { Total Debt }}{\text { Total asset }}
$$

\section{Pengembangan Hipotesis}

Pengaruh Beban Pajak Tangguhan terhadap Manajemen Laba

Beban pajak tangguhan diatur dalam Pernyataan Standar Akuntansi Keuangan (PSAK) No. 46 tentang Akuntansi Pajak Penghasilan. Beban pajak tangguhan dikelompokan berdasarkan perbedaan temporer dan perbedaan permanen. Pajak secara final, dan adanya non deductible expense ( biaya yang tidak boleh dikurangi) (Kamil et al., 2017).

Perbedaan temporer adalah perbedaan yang terjadi akibat perbedaan waktu pengakuan biaya atau pendapatan dalam laba akuntansi dan dalam laba fiskal. Perbedaan ini yang menyebabkan timbulnya biaya dan pendapataan pajak tangguhan dalam laporan keuangan. kenaikan kewajiban pajak tangguhan konsisten dengan perusahaan yang mengakui pendapatan lebih awal atau menunda biaya untuk tujuan pelaporan keuangan komersial pada periode tersebut untuk tujuan pelaporan 
keuangan komersial pada periode tersebut dibanding tujuan pelaporan pajak. tindakan perusahaan mengakui pendapatan lebih awal atau menunda biaya mengindikasikan bahwa manajemen melakukan manajemen laba pada laporan keuangan komersial. Semakin tinggi praktik manajemen laba, maka semakin tinggi kewajiban pajak tangguhan yang diakui oleh perusahaan sebagai beban pajak tangguhan.

Menurut penelitian (Lestari, 2018) beban pajak tangguhan berpengaruh positif terhadap manajemen laba dan memberikan pengaruh cukup besar karena manajemen melakukan praktik manajamen laba untuk penghematan pajak. Sama halnya dengan penelitan (Widiawati, 2019) menyatakan bahwa beban pajak tangguhan berpengaruh positif karena dengan tujuan menghindari pelaporan kerugian pada pelaporan tahun berikutnya.

Berdasarkan hasil uraian di atas, hipotesis pertama yang diajukan pada penelitian ini adalah sebagai berikut:

\section{H1: Beban pajak tangguhan berpengaruh positif terhadap manajemen laba}

\section{Pengaruh Profitabilitas terhadap Manajemen Laba}

Profitabilitas adalah kemampuan perusahaan dalam memperoleh laba dalam hubunganya dengan penjualan, total aset maupun modal sendiri (sartono:122). Dakam kaitanya dengan manajemen laba, profitabilias dapat memengaruhi manajer untuk melakukan manajemen laba. Karena jika profitabilitas yang didapat rendah, umumnya manajer akan melakukan tindak manajemen laba untuk menyelamatkan kinerja perusahaan dimata investor.

Profitabilitas merupakan rasio keuangan yang bisa mengukur tindakan manajemen laba perusahaan. Proksi yang dingunakan dalam penelitian ini ada return on assets (ROA). Profitabilitas merupakan salah satu indikator penting yang dapat digunakan untuk menilai suatu perusahaan. Selain untuk mengukur kemampuan perusahaan dalam menghasilkan laba, profitabilitas adalah hasil bersih dari berbagai kebijaksanaan dan keputusan.

Menurut (Lestari, 2018) profitabilitas berpengaruh terhadap manajamen laba karena profitabilitas merupakan kapasitas perusahaan untuk mendapatkan laba dimana masing-masing pengukuran dihubungkan dengan volume penjualan, total aset maupun modal sendiri. Sama halnya dengan penelitian (Kamil et al., 2017) yang menyatakan profitabilitas berpengaruh terhadap manajemen laba karena profitabilitas mencerminkan kinerja perusahaan sangat berpengaruh signifikan terhadap manajemen laba, dan hal ini disebabkan oleh adanya motivasi dari pihak manajemen atau manajer untuk memberikan laporan kinerja perusahaan yang baik, sehingga memicu terjadinya manajemen laba.

Berdasarkan hasil uraian di atas, hipotesis kedua yang diajukan pada penelitian ini adalah sebagai berikut:

\section{H2: Profitabilitas berpengaruh positif terhadap manajemen laba}

\section{Pengaruh Leverage terhadap Manajemen Laba}

Leverage adalah utang yang digunakan oleh perusahaan untuk membiayai asetnya dalam rangka menjalankan aktivitas operasionalnya. Dalam kaitanya dengan manajemen laba, leverage dapat memengaruhi manajer untuk melakukan manajemen laba. Semakin besar utang perusahaan makan semakin besar pula resiko yang dihadapi pemilik akan meminta tingkat keuntungan yang semakin tinggi agar perusahaan tersebut tidak terancam dilikuidasi. Rasio leverage menunjukkan besarnya aset yang dimiliki oleh perusahaan yang dibiayai dengan utang. Semakin tinggi nilai leverage maka resiko yang akan dihadapi investor akan semakin tinggi dan para investor akan meminta keuntungan yang semakin besar.

Leverage menunjukan proporsi pengunaan utang untuk membiayai investasinya. Semakin besar utang perusahaan maka semakin besar resiko yang akan dihadapi oleh investor sehingga investor akan meminta keuntungan yang lebih tinggi. Akibatnya kondisi tersebut mendorong manajemen perusahaan untuk melakukan praktik income smoothing.

Menurut penelitian Fandriani (2019) dan (Mahawyahrti \& Budiasih, 2017) leverage berpengaruh positif terhadap manajemen laba karena tingkat leverage yang tinggi akan memotivasi manajer untuk melakukan manajemen laba. Hal ini dikarenakan tingkat leverage yang tinggi akan memotivasi manajer untuk melakukan manajer untuk melakukan manajemen laba untuk dapat menaikkan laba perusahaan. manajer akan melakukan beberapa cara yang dapat menaikan laba perusahaan.

Berdasarkan hasil uraian di atas, hipotesis ketiga yang diajukan pada penelitian ini adalah sebagai berikut:

\section{H3: Leverage berpengaruh positif terhadap manajemen laba}

Variabel Independen

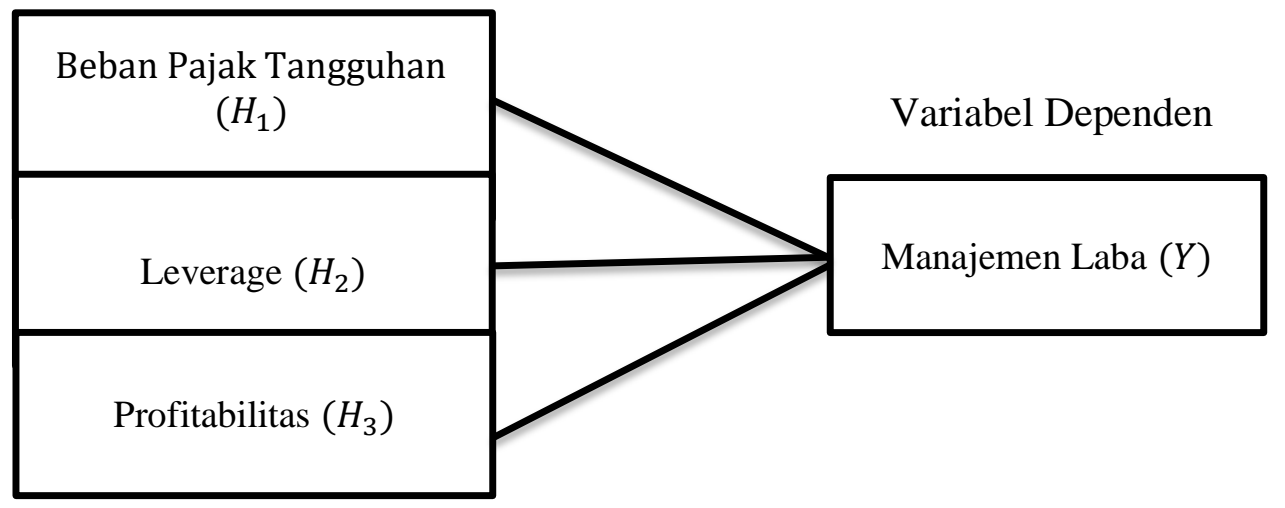

Gambar 1. Kerangka Konseptual 


\section{METODE}

Penelitian ini bertujuan untuk memperoleh bukti empiris mengenai analisis pengaruh beban pajak tangguhan, profitabilitas dan leverage terhadap manajemen laba. Penelitian ini menggunakan data sekunder yaitu dari laporan keuangan, laporan keuangan tahunan, dan laporan keberlanjutan perusahaan manufaktur dengan sub sektor konsumsi yang terdaftar di Bursa Efek Indonesia dalam periode 2018-2020. Sampel yang diakses pada website www.idx.co.id dan website masing-masing perusahaan.

Teknik pengambilan sampel yang digunakan dalam penelitian ini adalah Purposive sampling. Dengan total keseluruhan perusahaan manufaktur sub-sektor konsumsi yang terdaftar selama 2018-2020 yaitu 31 perusahaan, dan ada 3 perusahaan yang laporan tahunanya tidak tersedia di bursa efek indonesia sehingga peneliti mengurangi dari 31 perusahaan menjadi 28 perusahaan, dari 28 perusahaan di kali 3 karena tahun penelitian 2018-2020 sehingga terdapat 84 perusahaan data yang terpilih, namun terdapat data yang outlier.

Menurut Ghozali (2018) outlier adalah data yang terlihat sangat berbeda jauh dari observasi dan mucul dalam bentuk nila ekstrim. Selanjutnya 79 data tersebut dilakukan uji normalitas untuk mengetahui kenormalan distribusinya dan ditemukan sebanyak 5 data yang memiliki nilai ekstrim. Peneliti melakukan outlier dengan menggunakan unbalance yang dimana yang dikeluarkan hanya pada nilai yang terkena outlier dan data yang masih dibutuhkan tetap ada di dalam tabulasi data. Oleh karena itu, sebanyak empat data perlu di eliminasi. Berikut tabel 4.1 menyajikan perolehan sampel berdasarkan kriteria yang telah sesuai dengan kebutuhan penelitian.

1. Perusahaan pada sub sektor konsumsi yang terdaftar di Bursa Efek Indonesia berturut - turut selama tahun 20182020.

2. Perusahaan pada sub sektor konsumsi yang laporan tahunanya dapat diakses selama tahun 2018-2020

3. Perusahaan yang memiliki data lengkap terkait dengan variabel (Beban Pajak Tangguhan, Total Aset, Net Income, Arus Kas Operasi, Penjualan, Aset Tetap, Piutang) penelitian selama periode 2018-2020.

4. Perusahaan yang menerbitkan laporan keuangan dalam satuan mata uang rupiah.

5. Uji outlier

Tabel 1. Hasil Uji Statistik Deskriptif

\begin{tabular}{|c|c|}
\hline Kriteria Sampel & Jumlah \\
\hline $\begin{array}{l}\text { Perusahaan pada sub sektor konsumsi yang terdaftar di bursa efek } \\
\text { indonesia pada tahun } 2018-2020\end{array}$ & 31 \\
\hline $\begin{array}{l}\text { Perusahaan pada sub sektor konsumsi yang laporan tahunanya tidak } \\
\text { dapat diakses selama tahun } 2018-2020\end{array}$ & (3) \\
\hline $\begin{array}{l}\text { Perusahaan yang tidak menyajikan data lengkap terkait penelitian } \\
\text { tersebut. }\end{array}$ & 0 \\
\hline Total Sample Penelitian & 28 \\
\hline Tahun Penelitian 2018-2020 & 3 \\
\hline Total Observasi Penelitian selama 3 tahun 2018-2020 & 84 \\
\hline Jumlah Observasi Outlier & 5 \\
\hline Total Observasi Penelitian & 79 \\
\hline
\end{tabular}

Sumber: Data dioalah oleh penulis, 2021

Berikut operasionalisasi variabel yang digunakan pada penelitian ini:

Pengukuran manajemen laba dapat dihitung dengan cara mengunakan discretionary accrual, pengukuran discretionary accrual sebagai proksi manajemen laba karena sistem akuntansi akrual ini dapat memberikan peluang terhadap manajemen untuk dapat melakukan tindakan manajemen laba. Menurut Fandriani (2019) mengukur discretionary accrual dapat dirumuskan sebagai berikut:

$$
D A_{i t}=\frac{T A_{i t}}{A_{i t-1}}-N D A C_{i t-1}
$$

Keterangan

$D A_{i t}$

$T A_{i t}$

: Discretionary accruals perusahaan i pada periode ke $\mathrm{t}$

$A_{i t-1}$

: Total accruals perusahaan i pada periode ke $t$

: Total aset i pada periode ke $\mathrm{t}$

Beban pajak tanguhan adalah salah satu pendekatan yang dapat digunakan untuk mendeteksi adanya praktik manajemen laba yang dilakukan oleh manajemen perusahaan. Menurut Saputra (2018) untuk menghitung beban pajak tangguhan adalah sebagai berikut:

BPT = Beban Pajak Tangguhan

$$
\mathrm{BPT}=\frac{\text { Pajak } \text { Tangguhan }}{\text { Total Aset }-1}
$$

Peneliti menggunakan ROA karena ROA dapat menggambarkan seberapa besar pengelolaan atau penggunaan aset sebuah perusahaan untuk menghasilkan laba, dengan melihat seberapa besar laba bersih setelah pajak yang dihasilkan maka pihak manajemen dapat memilih apakah laba tersebut dibagikan sebagai dividen atau tidak. Adapun rumus ROA yang 
dikutip dari Widiawati (2019) adalah sebagai berikut:

$$
\text { Return On Assets }=\frac{\text { Laba bersih }}{\text { Total Aset }}
$$

Leverage dalam penelitian ini diukur dengan menggunakan Debt to Asset Ratio (DAR). DAR adalah rasio utang yang digunakan untuk mengukur perbandingan total utang dan total aset, dengan maksud lain seberapa besar aset suatu perusahaan yang dibiayai oleh utang atau seberapa besar utang suatu perusahaan berpengaruh terhadap pengelolaan aset. Adapun rumus DAR menurut (Suyoto et al., 2019) adalah sebagai berikut:

$$
\text { Debt to Asset Ratio }=\frac{\text { Total Debt }}{\text { Total Asset }}
$$

Berikut merupakan hasil persamaan regresi :

Dimana:

$$
Y=\alpha+\beta_{1} B p t+\beta_{2} \text { Prof }+\beta_{3} L e v+e
$$

Y : Variabel dependen (Manajemen Laba)

$\alpha \quad$ : Konstanta

$\mathrm{X}_{1} \quad$ : Beban Pajak Tangguhan

$\mathrm{X}_{2} \quad$ : Profitabilitas

$\mathrm{X}_{3} \quad$ : Leverage

e : Error term

\section{HASIL DAN PEMBAHASAN}

Analisis Statistik Deskriptif

Tabel 2. Hasil Uji Statistik Deskriptif

\begin{tabular}{lrrrrl}
\hline & N & Minimum & Maximum & Mean & $\begin{array}{c}\text { Std. } \\
\text { Deviation }\end{array}$ \\
\hline Manajemen Laba & 79 & $-0,50108$ & 0,20918 & $-0,0390565$ & 0.10385302 \\
\hline $\begin{array}{l}\text { Beban Pajak } \\
\text { Tangguhan }\end{array}$ & 79 & $-0,06749$ & 0,06211 & 0,0031692 & 0.01198118 \\
\hline Profitabilitas & 79 & -1.36932 & 8,30236 & 0,1279725 & 0.94830714 \\
\hline Leverage & 79 & 0,07357 & 8,20772 & 0,5749193 & 0.95333066 \\
\hline Valid N (listwise) & 79 & & & & \\
\hline Sumber: Data diolah menggunakan spss 26 & & &
\end{tabular}

\section{Uji Asumsi Klasik}

\section{Uji Normalitas}

Pengujian Normalitas bertujuan untuk mengetahui data memiliki distribusi normal atau tidak normal. Apabila memiliki distribusi data normal atau mendekati normal termasuk dalam model regresi yang baik. Nilai Asymp. Sig (2-tailed) yang di tunjukan pada tabel 3 sebesar 0,097 sehingga nilai signifikansi lebih besar dari 0,05 (0,097 > 0,05). Maka dapat disimpulkan bahwa data yang digunakan pada penelitian ini memiliki distribusi normal.

Tabel 3. Hasil Uji Normalitas

\begin{tabular}{cccc}
\hline & N & $\begin{array}{c}\text { Unstandardized } \\
\text { Residual }\end{array}$ & Kesimpulan \\
\hline $\begin{array}{c}\text { Normalitas } \\
\text { tailed) }\end{array}$ & 79 & 0,097 & $\begin{array}{c}\text { Data Terdistribusi } \\
\text { Normal }\end{array}$ \\
\hline
\end{tabular}

Sumber: Data diolah menggunakan spss 26

\section{Uji Multikolinieritas}

Uji multikolinearitas bertujuan untuk mendeteksi adanya korelasi yang tinggi antara variable independen dalam penelitian. Model regresi yang baik yaitu terbebas dari adanya multikolinearitas. Dalam menguji multikolinearitas dapat dilihay dari nilai Variance Inflatation Factors (VIF) dengan kriteria jika VIF suatu variable bebas <10, maka dapat disimpulkan bahwa variable bebas tersebut tidak terdapat multikolienaritas.

Tabel 4. Hasil Uji Multikolinieritas

\begin{tabular}{cccc}
\hline Variabel & Tolerance & VIF & Kesimpulan \\
\hline BPT & 0,544 & 1,837 & $\begin{array}{c}\text { Tidak Terjadi } \\
\text { Multikolienaritas }\end{array}$ \\
\hline PROF & 0,261 & 3,834 & $\begin{array}{c}\text { Tidak Terjadi } \\
\text { Multikolienaritas }\end{array}$ \\
\hline
\end{tabular}




\begin{tabular}{cccc}
\hline LEV & 0,260 & 3,842 & $\begin{array}{c}\text { Tidak Terjadi } \\
\text { Multikolienaritas }\end{array}$ \\
\hline
\end{tabular}

\section{Sumber: Data diolah menggunakan SPSS 26}

Berdasarkan table 4 di atas dapat dilihat bahwa nilai VIF dari seluruh variabel independent pada penelitian ini adalah $<10$, yaitu 1,837 untuk variabel Beban Pajak Tangguhan, 3,834 untuk variabel Profitabilitas, dan 3,842 untuk variabel Leverage. Dan untuk nilai Tolerance seluruh variabel independent adalah $>0,1$, yaitu 0,544 untuk variabel Beban Pajak Tangguhan, 0,261 untuk variabel Profitabilitas, dan 0,260 untuk variabel Leverage Sehingga dapat disimpulkan bahwa antar variabel independen tidak terjadi multikolinearitas atau tidak terjadi korelasi antar variabelnya.

\section{Uji Autokorelasi}

Pengujian ini menguji apakah dalam model regresi linear berganda ada korelasi antar kesalahan penggangu pada periode $\mathrm{t}$ dengan kesalahan pada periode $\mathrm{t}-1$ (sebelumnya). Autokorelasi biasanya muncul karna adanya observasi yang beruntutan sepanjang waktu berkaitanya suatu sama lain.

Dalam Penelitian ini dengan jumlah $\mathrm{N}=79$, dan jumlah variable sebanyak 3 maka angka DW sebesar 1,524 berdasarkan keputusan hasil penerimaan autokorelasi, nilai dW terletak pada -2 sampai +2 tidak terdapat autokorelasi, yang dapat diartikan bahwa pada data penelitian ini terbebas dari autokorelasi.

Tabel 5. Hasil Uji Autokorelasi

\begin{tabular}{crrrrr}
\hline Model & R & $\begin{array}{c}\text { R } \\
\text { Square }\end{array}$ & $\begin{array}{r}\text { Adjusted } \\
\text { R Square }\end{array}$ & $\begin{array}{r}\text { Std. Error of } \\
\text { the Estimate }\end{array}$ & $\begin{array}{l}\text { Durbin- } \\
\text { Watson }\end{array}$ \\
\hline 1 & 0,396 & 0,157 & 0,123 & 0,09726 & 1,524 \\
\hline
\end{tabular}

Sumber: Data diolah menggunakan SPSS 26

\section{Uji Heterokedesitas}

Pengujian heteroskedastisitas bertujuan untuk menguji terjadinya ketidaksamaan variance dari residual pengamatan satu ke lainya dalam model regresi. Berdasarkan dari hasil pengolahan data tabel 6 terlihat bahwa signifikansi (sig) antara semua variable lebih besar dari 0,05. Maka dapat diartikan bahwa data penelitian ini telah lolos uji heteroskedastisitas atau dengan kata lain data penelitian ini bersifat homogen.

Tabel 6. Hasil Uji Heterokedesitas

\begin{tabular}{ccc}
\hline Variabel & Nilai Sig. & Kesimpulan \\
BPT & 0,271 & Tidak Terjadi Heteroskedastisitas \\
PROF & 0,072 & Tidak Terjadi Heteroskedastisitas \\
LEV & 0,363 & Tidak Terjadi Heteroskedastisitas \\
\hline
\end{tabular}

Sumber: Data diolah menggunakan SPSS 26

Berdasarkan dari hasil Tabel di atas dapat dilihat bahwa signifikansi (sig) antara semua variabel independen adalah $>0,05$, yaitu 0,250 untuk variabel Beban Pajak Tangguhan, 0,05 untuk variabel Profitabilitas, dan 0,268 untuk variabel Leverage. Sehingga dapat disimpulkan bahwa data penelitian ini tidak terjadi fenomena heteroskedastisitas.

\section{Analisis Regresi Linear Berganda} berikut:

Hasil analisis regresi linear berganda dapat dilihat pada tabel 7, sehingga diperoleh persamaan regresi sebagai

$$
\mathrm{Y}=-0,002-0,214(\mathrm{BPT})+0,077(\mathrm{PROF})-0,080(\mathrm{LEV})
$$

Tabel 7. Hasil Uji Analisis Regresi Linear Berganda

\begin{tabular}{|c|c|c|c|c|c|c|}
\hline \multirow{6}{*}{1} & & \multicolumn{2}{|c|}{$\begin{array}{l}\text { Unstandardized } \\
\text { Coefficients }\end{array}$} & \multirow{3}{*}{$\begin{array}{c}\text { Standardized } \\
\text { Coefficients } \\
\text { Beta }\end{array}$} & \multirow{3}{*}{$\underset{-0,125}{\mathbf{t}}$} & \multirow{3}{*}{$\begin{array}{l}\text { Sig. } \\
0,901\end{array}$} \\
\hline & Model & B & Std. Error & & & \\
\hline & (Constant) & $-0,002$ & 0,017 & & & \\
\hline & $\mathrm{X}_{1}$ & $-0,214$ & 1,246 & $-0,025$ & $-0,172$ & 0,864 \\
\hline & $\mathrm{X}_{2}$ & 0,077 & 0,023 & 0,708 & 3,408 & 0,001 \\
\hline & $\mathrm{X}_{3}$ & $-0,080$ & 0,023 & $-0,737$ & $-3,547$ & 0,001 \\
\hline
\end{tabular}

Adapun penjelasan dari persamaan di atas adalah:

1. Nilai konstanta adalaj $-0,002$, yang berarti jika beban pajak tangguhan, profitabilitas dan leverage nilainya adalah 0 (nol), maka manajemen laba akan bernilai sebesar -0,0002 
2. Nilai koefisien beban pajak tangguhan sebesar $-0,214$ karena koefisien bertanda negatif yang menunjukan bahwa adanya hubungan yang tidak searah antara variable beban pajak tangguhan dengan manajemen laba.

3. Nilai koefisien profitabilitas sebesar 0,77 karena koefisien bertanda positif menujukan bahwa adanya hubungan yang searah antara variabel profitabilitas dengan manajemen laba

4. Nilai koefisien leverage sebesar - 0,080 karena koefisien bertanda negatif menunjukan bahwa adanya hubungan yang tidak searah antara variabel profitabilitas dengan manajemen laba.

\section{Uji Koefisien Determinasi ( $\left.\mathrm{R}^{2}\right)$}

Analisis koefisien deteminasi $\left(\mathrm{R}^{2}\right)$ bertujuan untuk mengetahui seberapa besar kemampuan variasi variabel independen menjelaskan variabel dependen. Sumbangan pengaruh yang diberikan variabel bebas atau variabel independen $(\mathrm{X})$ terhadap variabel terikat atau variabel dependen $(\mathrm{Y})$, atau dengan kata lain, nilai koefisien determinasi atau $\mathrm{R}^{2}$ ini berguna sebagai metode memprediksi dan melihat seberapa besar kontribusi pengaruh yang diberikan $\mathrm{X}$ secara simultan tehadap variabel $Y$.

Berdasarkan Tabel 4.9 di atas dapat dilihat bahwa nilai Adjusted R Square dari model regresi penelitian ini adalah sebesar 0,123 yang berarti bahwa seluruh variabel independen yang terdiri dari beban pajak tangguhan, profitabilitas dan leverage mampu menjelaskan variasi dari variabel dependen yaitu manajemen laba sebesar $12,3 \%$ sedangkan sisanya $(100 \%-12,3 \%=87,7 \%)$ dijelaskan oleh variabel-variabel lain di luar model penelitian.

Tabel 8. Hasil Uji R²

\begin{tabular}{|c|c|c|c|c|c|}
\hline \multicolumn{6}{|c|}{ Model Summary $^{b}$} \\
\hline $\begin{array}{l}\text { Model } \\
1\end{array}$ & $\begin{array}{l}\mathrm{R} \\
.396^{\mathrm{a}}\end{array}$ & $\begin{array}{l}\text { R Square } \\
.157\end{array}$ & $\begin{array}{l}\text { Adjusted R } \\
\text { Square } \\
.123\end{array}$ & $\begin{array}{l}\text { Std. Error of the } \\
\text { Estimate } \\
.09726\end{array}$ & $\begin{array}{l}\text { Durbin-Watson } \\
1.524\end{array}$ \\
\hline
\end{tabular}

Uji F

Uji $\mathrm{F}$ bertujuan untuk uji keragaman model apakah variabel- variabel bisa menjawab dari penelitian tersebut. Menurut (Ghozali, 2016) Uji F mempunyai tujuan untuk mengetahui apakah variabel independen dalam model memengaruhi variable dependen secara bersama-sama, yang dapat dilihat dari nilai sig 0,05 atau 5\%.

Berdasarkan Tabel 9 di bawah dapat dilihat bahwa nilai Sig yang dihasilkan pada uji F adalah 0,005, di mana nilai ini $<0,05$. Sehingga dapat disimpulkan bahwa model regresi variabel independen yang terdiri dari beban pajak tangguhan, profitabilitas, dan leverage secara bersama-sama berpengaruh signifikan terhadap variabel dependen yaitu manajemen laba.

Tabel 9. Hasil Uji F

\begin{tabular}{ccrrrrr}
\hline & Model & $\begin{array}{c}\text { Sum of } \\
\text { Squares }\end{array}$ & df & $\begin{array}{c}\text { Mean } \\
\text { Square }\end{array}$ & F & Sig. \\
1 & Regression & 0,132 & 3 & 0,044 & 4,643 & $\mathbf{0 , 0 0 5}^{\mathbf{b}}$ \\
& Residual & 0,711 & 75 & 0,009 & & \\
Total & 0,841 & 78 & & & \\
\hline
\end{tabular}

Sumber: Data diolah oleh peneliti, Tahun 2022

Uji T

Uji T berfungsi untuk mencari pengaruh antara variabel independen terhadap variabel dependen (Sabrina, 2019). Uji T berguna untuk mengetahui pengaruh variabel $\mathrm{X}$ secara partial terhadap variabel $\mathrm{Y}$.

\begin{tabular}{lrrrrr}
\multicolumn{7}{c}{ Tabel 10. Hasil Uji T } \\
\hline \multicolumn{7}{c}{$\begin{array}{c}\text { Unstandardized } \\
\text { Coefficients }\end{array}$} & $\begin{array}{c}\text { Standardized } \\
\text { Coefficients }\end{array}$ \\
& \multicolumn{1}{c}{ Model } & \multicolumn{1}{c}{$\begin{array}{c}\text { S } \\
\text { Std. Error }\end{array}$} & Beta & \multicolumn{1}{c}{ t } & Sig. \\
1 (Constant) & $-0,002$ & 0,017 & & $-0,125$ & $\mathbf{0 , 9 0 1}$ \\
BPT $\left(\mathrm{X}_{1}\right)$ & $-0,214$ & 1,246 & $-0,025$ & $-0,172$ & $\mathbf{0 , 8 6 4}$ \\
PROF $\left(\mathrm{X}_{2}\right)$ & 0,077 & 0,023 & 0,708 & 3,408 & $\mathbf{0 , 0 0 1}$ \\
LEV $\left(\mathrm{X}_{3}\right)$ & $-0,080$ & 0,023 & $-0,737$ & $-3,547$ & $\mathbf{0 , 0 0 1}$ \\
\hline
\end{tabular}

Sumber: Data diolah oleh peneliti, Tahun 2022

Berdasarkan hasil pengujian analisis uji t dari tabel tersebut pada model regresi linear berganda sebagai berikut:

1. Pengaruh beban pajak tangguhan terhadap manajemen laba

Berdasarkan hasil pengujian diatas beban pajak tangguhan diperoleh nilai sig. sebesar 0,782 yang berarti lebih besar dari $0,05(0,782>0,05)$ dan nilai unstandardized $-0,316$ dengan arah negatif. Maka dapat disimpulkan bahwa $\mathbf{H}_{\mathbf{1}}$ ditolak, berarti variable beban pajak tangguhan tidak berpengaruh terhadap manajemen laba. 
2. Pengaruh profitabilitas terhadap manajemen laba

Berdasarkan hasil pengujian diatas profitabilitas diperoleh nilai sig. sebesar 0,000 yang berarti lebih kecil dari 0,05 $(0,000<0,05)$ dan nilai unstandardized 0,84 dengan arah positif. Maka dapat disimpulkan bahwa $\mathbf{H} \mathbf{H}_{\mathbf{1}}$ diterima, berarti variable profitabilitas berpengaruh positif terhadap manajemen laba.

3. Pengaruh leverage terhadap manajemen laba

Berdasarkan hasil pengujian diatas leverage diperoleh nilai sig. sebesar 0,000 yang berarti lebih kecil dari 0,05 $(0,000<$ $0,05)$ dan nilai unstandardized -0,90 dengan arah negatif. Maka dapat disimpulkan bahwa $\mathbf{H}_{\mathbf{1}}$ diterima, berarti variable leverage berpengaruh negatif terhadap manajemen laba.

\section{PEMBAHASAN}

\section{Beban Pajak Tangguhan Tidak Berpengaruh Terhadap Manajemen Laba}

Berdasarkan hasil pengujian hipotesis di atas menunjukan bahwa beban pajak tangguhan tidak berpengaruh terhadap manajemen laba. Artinya bahwa perubahan nilai beban pajak tangguhan yang dimiliki perusahaan tidak mempengaruhi tindakan manajemen laba yang akan dilakukan oleh perusahaan tersebut.

Hasil penelitian ini sejalan dengan penelitian (W. Setyawan \& Wulandari, 2021) dan (Widiawati, 2019) yang menyatakan bahwa beban pajak tangguhan tidak berpengaruh terhadap manajemen laba. Hal ini disebabkan pihak manajemen memiliki keterbatasan merekayasa akun dari beban pajak tangguhan karena adanya peraturan mengenai beban pajak tangguhan dalam peraturan perpajakan yang berlaku. Sehingga variabel ini tidak menjadi faktor pihak manajemen dalam melakukan tindakan manajemen laba di perusahaan.

Hasil penelitian ini tidak sejalan dengan penelitian Lestari (2018), Sari et al., (2019), (Fitriya et al., 2020) dan (Suputra, 2017) yang menyatakan Beban Pajak Tangguhan berpengaruh positif terhadap Manajemen Laba.

\section{Profitabilitas Berpengaruh Positif Terhadap Manajemen Laba}

Berdasarkan hasil pengujian hipotesis di atas menunjukan bahwa profitabilitas berpengaruh positif terhadap manajemen laba. Artinya bahwa semakin tinggi profitabilitas yang dimiliki perusahaan maka semakin besar perusahaan (pihak manajemen) tersebut akan melakukan tindakan manajemen laba.

Hasil penelitian ini sejalan dengan penelitian (Fitriya et al., 2020) dan (Widiawati, 2019) yang menyatakan profitabilitas berpengaruh terhadap manajemen laba. Hal ini disebabkan laba yang dihasilkan perusahaan selama tahun berjalan dapat menjadikan indikator terjadinya manajemen laba. Perusahaan yang mengalami profitabilitas rendah, cenderung melakukan manajemen laba dalam bentuk menaikkan laba, sedangkan perusahaan yang memiliki profitabilitas tinggi cenderung melakukan manajen laba dalam bentuk menurunkan laba atau cenderung tidak melakukan tindak manajemen laba. karna jika perusahaan yang memiliki profitabilitas tinggi akan menunjukan laba yang tinggi dan pajak akan semakin tinggi.

Hasil penelitian ini tidak sejalan dengan penelitian (Fandriani, 2019) yang menyatakan Profitabilitas tidak berpengaruh terhadap manajemen laba.

\section{Leverage Berpengaruh Negatif Terhadap Manajemen laba}

Berdasarkan hasil pengujian hipotesis di atas menunjukan bahwa leverage berpengaruh negatif terhadap manajemen laba. Artinya bahwa semakin tinggi leverage yang dimiliki perusahaan maka semakin kecil perusahaan (pihak manajemen) tersebut akan melakukan tindakan manajemen laba.

Hasil ini penelitian ini sejalan dengan penelitian ini dari Dewi \& Wirawati (2019) dan Savitri \& Priantinah (2019) yang mengemukakan bahwa leverage berpenngaruh negatif terhadap manajemen laba.

Besarnya perusahaan dalam menggunakan pembiayaan hutang, maka nilai leverage yang dimiliki oleh perusahaan akan semakin tinggi, sehingga pengawasan yang dilakukan oleh pihak kreditur terhadap perusahaan akan semakin ketat. Karena perusahaan memiliki tingkat hutang yang tinggi maka perusahaan akan memerlukan bantuan dana dari pihak ketiga baik dari pihak kreditur maupun investor. Upaya untuk mendapatkan kepercayaan dari kreditur atau investor perusahaan akan mengurangi tindakan manajemen laba, karena apabila perusahaan melakukan praktik manajemen laba maka kreditur dan investor cendurung akan tidak mempercayai laporan yang diberikan oleh perusahaan.

Hasil penelitian ini tidak sejalan dengan penelitian (Maslihah, 2019) yang menyatakan Leverage berpengaruh positif terhadap Manajemen Laba.

\section{KESIMPULAN DAN SARAN \\ Kesimpulan}

Penelitian ini bertujuan untuk menguji apakah beban pajak tangguhan, profitabilitas dan leverage berpengaruh terhadap manajemen laba. Dalam penelitian ini yang menjadi subjek adalah perusahaan manufaktur sub-sektor konsumsi yang listing di Bursa Efek Indonesia (BEI). Pengumpulan data dalam penelitian ini dilakukan dengan cara menganalisis laporan keuangan dan tahunan yang diambil dari situs resmi BEI pada tahun 2018-2020 dengan sampel penelitian sebanyak 84 data. Dalam penentuan sampel akhir, peneliti melakukan outlier atas beberapa perusahaan untuk mengatasi masalah normalitas pada pengujian data, sehingga total observasi yang diteliti berjumah 79 observasi.

Penelitian ini menggunakan manajemen laba sebagai variabel terikat. Manajamen laba merupakan suatu tindakan yang di lakukan pihak manajemen untuk me naik atau turunkan laba sesuai dengan kepentingan pihak tertentu. Sedangkan variabel bebas pada penelitian ini adalah beban pajak tangguhan, profitabilitas dan leverage. Beban pajak tangguhan adalah perbedaan temporer dari kebijakan fiskal dengan kebijakan akuntansi maka terjadinya beban pajak tangguhan. Profitabilitas merupakan ukuran kemampuan yang menghasilkan laba atas aset yang dimilikinya. Leverage adalah perbandingan antara total kewajiban dengan total aset perusahaan. Rasio ini menunjukkan besarnya besar aset yang dimiliki perusahaan yang 
dibiayai dengan utang.

Berdasarkan penelitian yang dilakukan oleh peneliti, maka diperoleh kesimpulan yaitu:

1. Beban pajak tangguhan tidak berpengaruh terhadap manajemen laba.

2. Profitabilitas berpengaruh positif terhadap manajemen laba.

3. Leverage berpengaruh negatif terhadap manajemen laba.

\section{Implikasi}

Implikasi Teoritis

Berdasarkan hasil penelitian yang diperoleh, peneliti dapat memberikan beberapa implikasi teoritis sebagai berikut:

a. Bagi peneliti

Peneliti dapat memperoleh pemahaman tentang beban pajak tangguhan, profitabilitas dan leverage terhadap manajemen laba. Penelitian ini dapat menjelaskan teori sebelumnya yaitu mengenai teori akuntansi positif demi pengkajian ulang atau pengembangan lanjut yang dihubungkan dengan manajemen laba

b. Bagi Peneliti Selanjutnya

Penelitian ini dapat dijadikan literatur dalam melakukan penelitian selanjutnya yang berkaitan dengan variabel beban pajak tangguhan, profitabilitas dan leverage terhadap manajemen laba.

Implikasi Praktis

Berdasarkan hasil penelitian yang diperoleh, peneliti dapat memberikan beberapa implikasi praktis sebagai berikut:

a. Bagi Perusahaan

Perusahaan dapat bersifat transparan terhadap aktivitas bisnis yang dijalani. Para pemimpin ataupun investor diharapkan mengawasi secara internal atas kinerja yang dihasilkan perusahaan agar dapat meminimalkan terjadinya praktik manajemen laba.

b. Bagi Investor

Bagi investor menjadi masukan sebelum melakukan investasi, seperti tidak hanya melihat dari sisi kinerja keuangan namun harus memperhatikan sikap tanggung jawab dan transparasi dari perusahaan tersebut.

\section{Keterbatasan Penelitian}

Saat melakukan penelitian, peneliti memiliki beberapa keterbatasan diantaranya:

a. Penelitian ini hanya melakukan pengujian pada variabel beban pajak tangguhan, profitabilitas dan leverage terhadap manajemen laba pada kurun waktu 2018-2020, sehingga variabel diluar dari variabel tersebut tidak memiliki implikasi pada penelitian ini dan kondisi pada periode lain di luar penelitian bisa menjadi berbeda.

b. Untuk menelitian ini proksi untuk beban pajak tangguhan menggunakan DTE sedangkan untuk proksi profitabilitas menggunakan proksi return of aset (ROA) dan leverage debt asset ratio (DAR).

\section{Rekomendasi Bagi Penelitian Selanjutnya}

Berdasarkan kesimpulan dan keterbatasan yang telah dihasilkan dalam penelitian ini, untuk tujuan perbaikan pada hasil penelitian yang akan datang maka penulis memberikan saran:

1. Menambahkan atau menguji variabel lainnya yang diduga dapat mempengaruhi manajemen laba dalam perusahaan, seperti ukuran perusahaan, solvabilitas dan perencanaan pajak.

2. Melakukan penambahan jumlah populasi, misalnya dengan menjadikan seluruh perusahaan manufaktur atau seluruh perusahaan yang terdaftar di Bursa Efek Indonesia sebagai populasi.

3. Penelitian selanjutnya dapat menggunakan proksi lain dalam mengukur Beban Pajak Tangguhan, Profitabilitas, Leverage, dan Manajemen Laba, seperti ROE, DER dan GPM

\section{DAFTAR PUSAKA}

Anak Agung Mas Rattih Astari, I. K. S. (2017). Faktor-Faktor Yang Mempengaruhi Manajemen Laba Fakultas Ekonomi dan Bisnis Universitas Udayana ( Unud ), Bali , Indonesia Fakultas Ekonomi dan Bisnis Universitas Udayana ( Unud ), Bali , Indonesia ABSTRAK Perkembangan dalam dunia bisnis sekarang ini telah. 20, 290-319.

Anjarwi, A. W., Administrasi, F. I., \& Brawijaya, U. (2019). Implikasi perencanaan pajak dan beban pajak tangguhan terhadap manajemen laba perusahaan. 1, 26-31.

Ardiyansyah, M. (2013). Pengaruh Corporate Governance, Leverage Dan Profitabilitas Terhadap Manajemen Laba Pada Perusahaan Manufaktur Sektor Industri Barang Konsumsi Yang Terdaftar Di Bei Periode 2009-2013. 1-17.

Baraja, L. M., Basri, Y. Z., \& Sasmi, V. (2019). Pengaruh Beban Pajak Tangguhan, Perencanaan Pajak Dan Aktiva Pajak Tangguhan Terhadap Manajemen Laba. Jurnal Akuntansi Trisakti, 4(2), 191. https://doi.org/10.25105/jat.v4i2.4853

Dewi, P. E. P., \& Wirawati, N. G. P. (2019). E-Jurnal Akuntansi Universitas Udayana Pengaruh Leverage Terhadap Manajemen Laba Dengan Corporate Governance Sebagai Variabel Pemoderasi Fakultas Ekonomi dan Bisnis Universitas Udayana ( Unud ), Bali , Indonesia Pendahuluan Laporan keuangan adalah bentuk. E-Jurnal Akuntansi Universitas Udayana, 27, 505-533.

Esra Louvisa, D., Tarigan, L., \& Sembiring Carolina, C. F. (2017). Pengaruh Profitabiltas Dan Struktur Modal Terhadap Kinerja 
Perusahaan The Influence of Profitabilities and Capital Structure to Company Performance. 2(2), 52-64.

Fandriani, V. (2019). Pengaruh Surplus Arus Kas Bebas, Ukuran Perusahaan, Leverage Dan Kualitas Audit Terhadap Manajemen Laba. Diponegoro Journal of Accounting, 7(4), 505-514.

Fitriya, A. V., Maslichah, \& Mawardi, M. C. (2020). E-JRA Vol. 09 No. 07 Agustus 2020 Fakultas Ekonomi dan Bisnis Universitas Islam Malang. 09(07), 83-95.

Kamil, I., Ariyani, M., I, C. K., Manajemen, A. M., Ditinjau, L., Faktor, D., Pajak, B., Jurnal, L., \& Insan, O. (2017). Manajemen Laba Ditinjau Dari Faktor Beban Pajak Tangguhan, Profitabilitas dan Leverage. 2(2), 259-270.

Khudhair, D. Z., Al-Zubaidi, F. K. A., \& Raji, A. A. (2019). The effect of board characteristics and audit committee characteristics on audit quality. Management Science Letters, 9(2), 271-282. https://doi.org/10.5267/j.msl.2018.11.012

Lestari, F. A. P. (2018). Pengaruh Profitabilitas Dan Beban Pajak Tangguhan Terhadap Manajemen Laba Fibria Anggraini Puji Lestari Program Studi Informatika , FTIK Universitas Indraprasta PGRI. 10(3), 270-278.

Mahawyahrti, T., \& Budiasih, G. N. (2017). Asimetri Informasi, Leverage, dan Ukuran Perusahaan pada Manajemen Laba. Jurnal Ilmiah Akuntansi dan Bisnis, 11(2), 100. https://doi.org/10.24843/jiab.2016.v11.i02.p05

Maslihah, A. (2019). Pengaruh profitabilitas, aktiva pajak tangguhan, perencanaan pajak, dan leverage terhadap manajemen laba. 1(1), 30-45. https://doi.org/10.24964/japd.v1i1.769

Nalarreason, K. M., T, S., \& Mardiati, E. (2019). Impact of Leverage and Firm Size on Earnings Management in Indonesia. International Journal of Multicultural and Multireligious Understanding, 6(1), 19. https://doi.org/10.18415/ijmmu.v6i1.473

RAHMANTO, K. (2017). Pengaruh Beban Pajak Tangguhan, Leverage Terhadap Manajemen Laba Melalui Manipulasi Riil(Studi Empiris Perusahaan Manufaktur 2010-2016). Jurnal Akuntansi AKUNESA, 5(2).

Saputra, Y. (2018). Pengaruh Perencanaan Pajak, Beban Pajak Tangguhan Dan Leverage Terhadap Praktik Manajemen Laba. 1(6), 155-170.

Sari, R. N., Hardiyanto, A. T., \& Simamora, P. (2019). Perusahaan Manufaktur Yang Terdaftar Di Bursa Efek Indonesia Periode 2012 - 2017 1) Mahasiswa Fakultas Ekonomi Universitas Pakuan 2) Dosen Fakultas Ekonomi Universitas Pakuan 3 ) Dosen Fakultas Ekonomi Universitas Pakuan.

Savitri, D., \& Priantinah, D. (2019). Pengaruh Leverage Terhadap Manajemen Laba Dengan Corporate Governance Sebagai Variabel Pemoderasi Pada Perusahaan Manufaktur Sektor Aneka Industri Yang Terdaftar Di Bei Periode 2013-2016. Nominal: Barometer Riset Akuntansi dan Manajemen, 8(2),179-193. https://doi.org/10.21831/nominal.v8i2.26543

Setyawan, B., \& Harnovinsah. (2014). Pengaruh Beban Pajak Tangguhan, Profitabilitas, Dan Perencanaan Pajak Terhadap Manajemen Laba. 15-40.

Setyawan, W., \& Wulandari, S. (2021). Pengaruh Perencanaan Pajak, Beban Pajak Tangguhan dan Profitabilitas Terhadap Manajemen Laba (The Effect of Tax Planning, Deferred Tax Expenses, and Profitability on Earning Manajemen ). 2(02), 169-178.

Suputra, D. (2017). Pengaruh Mekanisme Corporate Governance dan Beban Pajak Tangguhan terhadap Manajemen Laba (Studi Empiris pada Perusahaan Manufaktur yang Terdaftar di Bursa Efek Indonesia Periode 2014-2016). E-Jurnal Akuntansi Universitas Udayana, 20(3), 2045-2072.

Suyoto, H., Dwimulyani, S., Trisakti, U., Data, U. K., Data, U. N., Setelah, R., Outlier, U., \& Laba, M. (2019). Pengaruh Leverage Dan Perencanaan Pajak Terhadap. 1-9.

Uwuigbe, U., Ranti, U. O., \& Bernard, O. (2015). Assessment of the Effects of Firms Characteristics on Earnings Management of Listed Firms in Nigeria. Asian Economic and Financial Review, 5(2), 218-228.

https://doi.org/10.18488/journal.aefr/2015.5.2/102.2.218.228

Widiawati, L. (2019). Pengaruh beban pajak tangguhan dan profitabilitas terhadap manajemen laba. 15(2), 7-15. 
Yogi, L. M. D. P., \& Damayanthi, I. G. A. E. (2016). Pengaruh Arus Kas Bebas, Capital Adequacy Ratio Dan Good Corporate Governance Pada Manajemen Laba. 15, 1056-1085.

www.idx.co.id

www.spssindonesia.com 